\title{
A Comprehensive Review on Vitamin D as a Novel Therapeutic Agent in Chronic Obstructive Pulmonary Disease
}

Amber Saleem 1 , Shayka Sharif 2 , Sommer Jarvis ${ }^{3}$, Nikolaos Madouros ${ }^{4}$, Evgenia Koumadoraki 2 , Safeer Khan ${ }^{2}$

1. Family Medicine, California Institute of Behavioral Neurosciences \& Psychology, Fairfield, USA 2. Internal Medicine, California Institute of Behavioral Neurosciences \& Psychology, Fairfield, USA 3. Anatomy/Cell Biology, California Institute of Behavioral Neurosciences \& Psychology, Fairfield, USA 4. Surgery, California Institute of Behavioral Neurosciences \& Psychology, Fairfield, USA

Corresponding author: Amber Saleem, ambersaleem212@gmail.com

\begin{abstract}
Vitamin D has been playing an important role in the treatment of lung diseases. The non-calcemic effects of this vitamin and its role in chronic obstructive pulmonary disease (COPD) has drawn significant attention recently. Many studies have been conducted to explore the relationship between the two. We tested the hypothesis that vitamin D can act as an effective therapeutic agent for COPD by reviewing the correlation between the two and effectiveness along with the safety of supplemental vitamin D when used to treat chronic bronchitis and emphysema through clinical trials. An electronic search was conducted using combinations of keywords "vitamin D" and "COPD" from PubMed and Google scholar. Only relevant, human studies of all types were included from the last decade. A total of 36 articles were selected for review. Observational studies indicate a correlation between low serum 25(OH)D levels and obstructive lung disease pathology as well as clinical outcomes. Moreover, clinical trials were aimed to understand the impact of the use of vitamin $\mathrm{D}$ in improving disease indexes. These clinical trials used different drug regimes, mode of administration, and intervention duration with contrasting outcomes.
\end{abstract}

Hypovitaminosis D is a common and harmful variant of this group of obstructive lung diseases, and correcting this deficiency can improve exacerbations, inflammation, lung functions, symptoms, and quality of life. These benefits are more prevalent in patients with low baseline serum 25 hydroxyvitamin $\mathrm{D}(25(\mathrm{OH}) \mathrm{D})$ levels. Peroral is the most frequently used route of drug administration, however, further work is required to explore the pharmacological properties of vitamin D. There was not enough literature available about the safety of the drug of intervention.

Received 12/09/2020 Review began 01/19/2021 Review ended 01/28/2021 Published 02/03/2021

๑) Copyright 2021 Saleem et al. This is an open access article distributed under the terms of the Creative Commons Attribution License CC-BY 4.0., which permits unrestricted use, distribution, and reproduction in any medium, provided the original author and source are credited.
Categories: Internal Medicine, Pulmonology

Keywords: vitamin d, copd, treatment, supplementation

\section{Introduction And Background}

"Chronic obstructive pulmonary disease (COPD) has affected 65 million people globally and is expected to become the third most common cause of mortality by 2030 - World Health Organization” [1].

COPD is a group of obstructive airway diseases that involves chronic bronchitis and emphysema. Smoking and other air pollutants are a leading cause of the systemic inflammatory response. Host factors like genetic abnormalities, abnormal lung development, and accelerated aging also play an important role in developing the disease [2]. Tobacco smoke decreases peak lung functions and increases age-related decline [3]. Currently, inhaled corticosteroids, theophylline, and long-acting beta- 2 agonist can effectively manage the disease symptoms and improve quality of life, but nothing has proven to cure the disease or reduce mortality [4]. A total of 3.2 million deaths have been reported by COPD worldwide in 2015 [5]. Mortality is directly related to acute exacerbations and systemic comorbidities of the disease [6].

Ergocalciferol (D2) and cholecalciferol (D3) are two forms of fat-soluble vitamin D. It can be obtained from diets such as fortified food, fish, and dietary supplements. Still, more than $80 \%$ of it is produced in the skin under UV radiation. In the liver, vitamin $\mathrm{D} 3$ is then hydroxylated to $25(\mathrm{OH}) \mathrm{D}$, a marker for serum vitamin $\mathrm{D}$ levels because of its long half-life [7]. 1,25(OH)2D (calcitriol) is an active form of this vitamin formed by hydroxylation of 25(OH)D, and it is an excellent ligand for vitamin D receptor (VDR). These receptors (VDR) and vitamin D binding proteins (VDBP) are present in multiple organ systems like lungs, brain, skeletal muscle, immune cells, pancreas, breast, and colon, in addition to the organs of bone health, which plays an important role in pathophysiology behind its extraskeletal effects [8]. We are familiar with its roles in calcium, phosphorus, and bone metabolism for centuries [9]. Recently there has been increased interest in the immunomodulatory and anti-inflammatory effects of this vitamin and its correlation with chronic diseases, particularly COPD [10]. 


\section{Cureus}

Vitamin D deficiency is a global health problem and is more common in populations with decreased sun exposure, limited mobility, and chronic diseases [11]. COPD and vitamin D share pathophysiological similarities, and many studies have shown a negative correlation between the two [12]. In relation to obstructive lung diseases and the role of supplemental calcitriol in managing disease outcomes of obstructive lung disease, hypovitaminosis D is an ongoing debate. Despite many clinical trials in this field, little is known about the efficacy, effective dosing regimes, and safety of its supplementation. The purpose of this evidence-based study is to review what impact this nutritional deficiency has on disease progression and how correcting this deficiency can help. Clinical trials from the last 10 years will be explored to find out more about the benefits and pharmacological properties of vitamin $\mathrm{D}$ supplements used to treat this obstructive lung disease and how baseline serum 1,25(OH)2D levels affect these trials' results. This research can help provide some evidence to the already established hypothesis that vitamin D can be a novel therapeutic agent for COPD. It will also provide grounds for new researchers to further work in required fields where more evidence is needed.

\section{Review}

\section{Methods}

Search Method and Strategy

We conducted a thorough literature search of electronic databases PubMed, Medline, PubMed Central, Google Scholar, but PubMed remained our main database. Few articles or facts were obtained from gray literature and the web page VitaminDwiki.

A search was generated by typing combinations of keywords vitamin D, COPD, treatment, and supplementation. All articles with full literature available were included. If literature was not available for some articles, we tried to contact the author or applied institutional access to reach the subject. The number of articles by typing each keyword can be seen in Table 1 .

\begin{tabular}{|l|l|l|}
\hline Keyword & Number of articles & Database \\
\hline Vitamin D & 28,083 & PubMed \\
COPD & 32,759 & PubMed \\
COPD treatment & 26,725 & PubMed \\
Vitamin D + COPD & 211 & PubMed \\
\hline
\end{tabular}

\section{TABLE 1: Search Results}

COPD: chronic obstructive pulmonary disease

Study Selection and Data Extraction

We reviewed mixed studies (observational, experimental, review articles, and meta-analyses) to see potential effects of low serum25(OH)D levels on COPD and Clinical trials, in particular, to concentrate more on the supplemental use of vitamin D in treating COPD. Our areas of interest would be efficacy, dosing regimes, duration of therapy, and safety profile of vitamin D and how baseline serum vitamin D levels in the intervention group play with the results.

Study selection and data extraction were performed by first scanning through the titles and then by applying Inclusion exclusion criteria (Table 2) and reading through the whole articles. Some clinical trials were taken from google scholar and VitaminDwiki. 


\section{Cureus}

Inclusion criteria

Age of literature: 10 years

Language: English

Human Studies

Patients diagnosed with COPD
Exclusion criteria

Studies older than 10 years

Language other than English

Animal studies

Articles with abstract only

The study should explain the correlation between serum levels of vitamin D and COPD or supplementation of vitamin D in COPD treatment

\section{TABLE 2: Inclusion and Exclusion Criteria}

COPD: chronic obstructive pulmonary disease

Quality Check

The entire method was performed ethically and scientifically. Quality appraisal for individual studies and statistical analysis was not done.

\section{Results}

Search results from PubMed showed 211 articles in the last 10 years. Twenty articles were collected from other sources like google scholar, gray literature, and a web page VitaminDwiki. After removing duplicates, 220 articles were screened through the titles or abstract. One hundred and fifty-five studies were excluded, and out of 65 retrieved articles, some more studies were removed based on an animal model, cellular, or molecular levels (Figure 1).

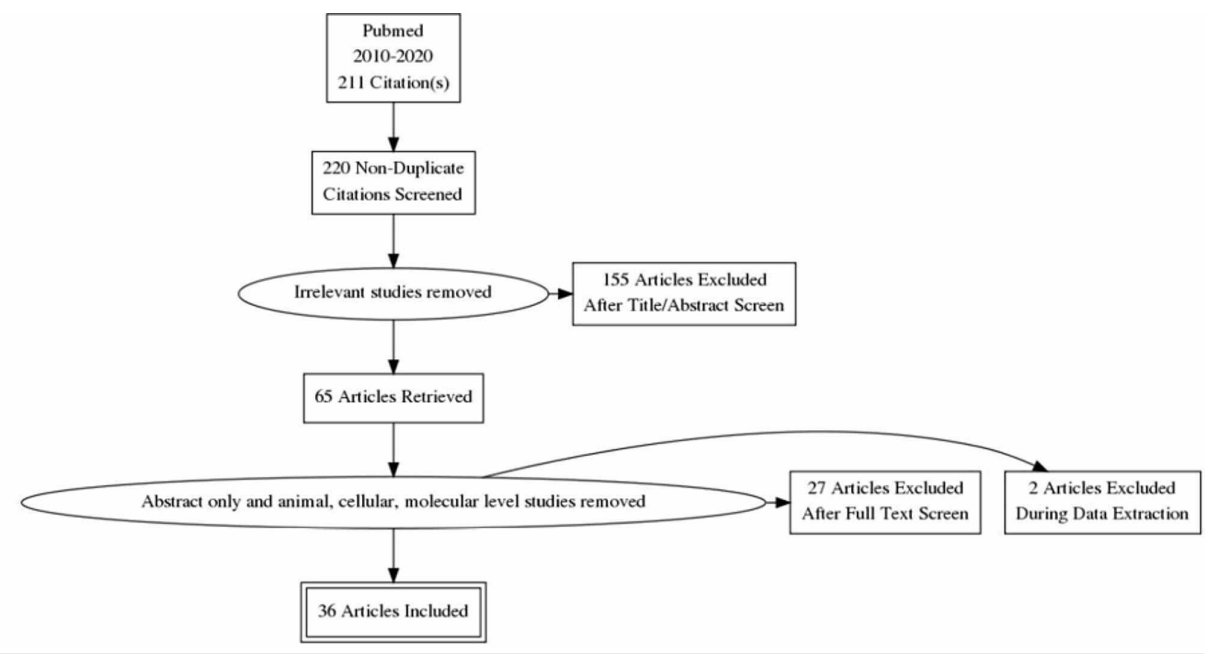

FIGURE 1: Flow Diagram for Study Selection

Out of 36 final studies, 13 were observational studies performed on 48,479 disease affected patients focusing on correlation and effects of hypovitaminosis D on clinical outcomes of COPD. Three are review articles with an undefined number of participants and two meta-analyses of nine cohort studies and 25 randomized clinical trials, respectively. Regarding the benefits and role of vitamin D supplements in the treatment of COPD, we included 18 clinical trials from the last ten years that discussed mostly the effects on disease exacerbations, lung functions or spirometry indices, quality of life, muscle strength, and physical exercise. The total number of participants in these trials was 4532 (Control+ Intervention arm).

\section{Discussion}

Vitamin D and its role in extraskeletal diseases have gained enormous popularity in the last decade. Few 
autoimmune, respiratory, neurodegenerative, and mental health problems are among those extra skeletal problems [8]. Like its other counterparts, scientists have been trying to explore this vitamin's effects and its deficiency on obstructive lung diseases. There has been plenty of work going on in this field for years. The purpose of this study is to review the literature and figure out where we stand. Do we have enough evidence to say that this vitamin can act as a novel therapeutic agent for emphysema and chronic bronchitis?

Relationship Between Vitamin D and COPD

Serum 25(OH)D levels below $20 \mathrm{ng} / \mathrm{mL}(50 \mathrm{nmol} / \mathrm{L})$ is defined as vitamin $D$ deficiency between $21-29 \mathrm{ng} / \mathrm{mL}$ $(52.5-72.5 \mathrm{nmol} / \mathrm{L})$ as insufficiency and $30 \mathrm{ng} / \mathrm{mL}$ as normal levels by US endocrinology society [13]. The prevalence of this deficiency is higher among COPD patients than in healthy control populations [14]. This, too, was more significant among patients with recent exacerbations or hospitalizations [15]. The mechanism behind this can involve decreased sun exposure due to limited mobility, aging as this group of diseases belongs to old age, chronic use of steroids that increase the breakdown of this vitamin, chronic inflammatory processes, or smoking that has a molecular relationship with the vitamin D signaling pathway [16].In light of the recently published literature, the following are the presumed effects of decreased 25(OH)D levels on the clinical outcomes of emphysema and chronic bronchitis (Figure 2). However, the search for more evidence is still ongoing.

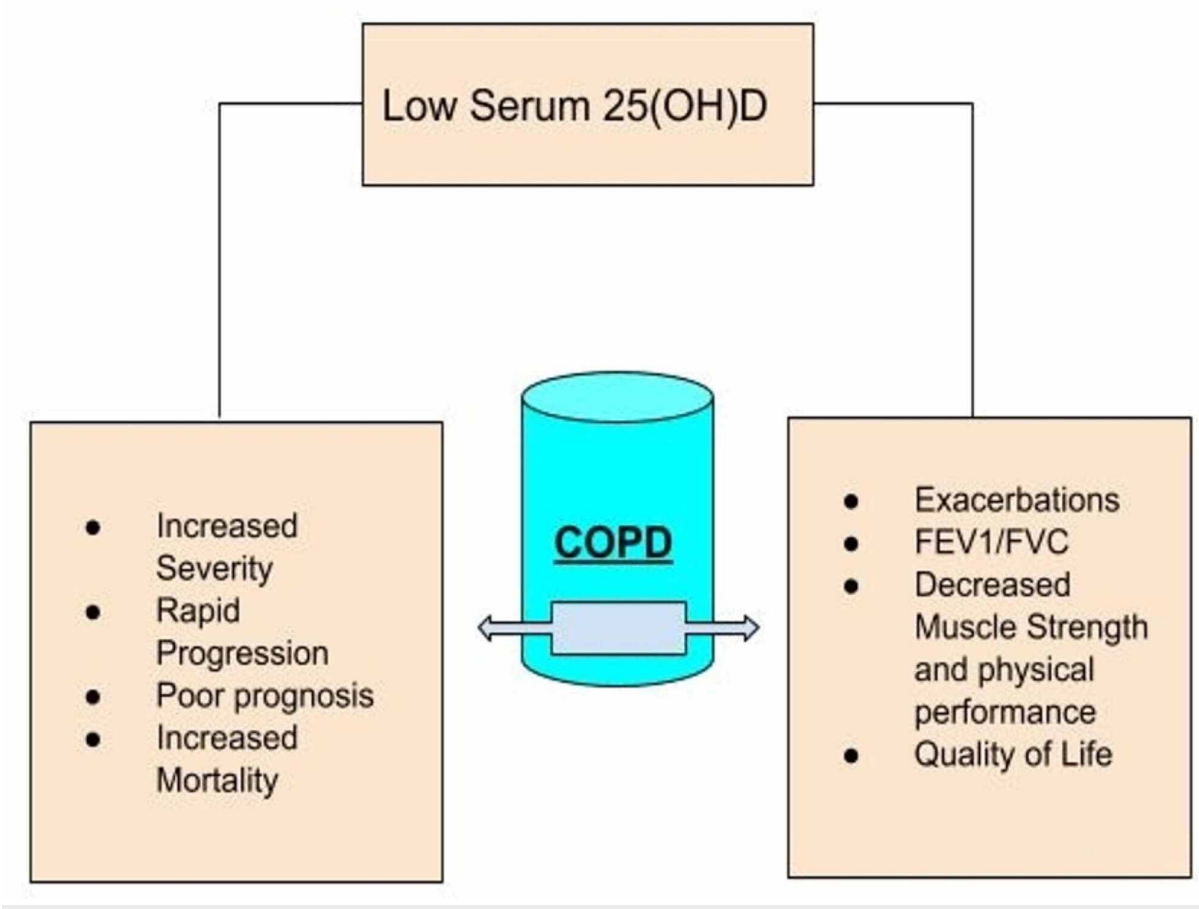

\title{
FIGURE 2: Effects of Low 25(OH)D Levels on Clinical Outcomes of COPD
}

COPD: chronic obstructive pulmonary disease

\begin{abstract}
A negative correlation has been reported between disease severity and vitamin D levels [17,18]. Kim et al. proposed that severely low $25(\mathrm{OH}) \mathrm{D}$ levels $(<10 \mathrm{ng} / \mathrm{mL})$ in male patients with COPD can increase the severity and progression of emphysema [19]. Acute exacerbation's timings and frequency were also observed to be increased under the effect of this deficiency in some studies [20,11,4], and some showed the opposite results [10]. When studied in hospitalized or chronically ill populations, an increased rate of deaths was seen among obstructive lung disease populations with severe Vitamin D deficiency, making it a poor prognostic factor with increased mortality rate and poor disease outcome [21-24]. Xu et al. conducted the largest crosssectional meta-analysis showing a positive correlation between lung function indices (FEV1/FVC) and 25(OH)D [25]. Quality of life, muscle strength, and exercise tolerance are other disease variables with fewer observational studies. Still, all of these variables have a negative correlation with serum vitamin D levels $[8,26,27]$.
\end{abstract}

Clinical Trials Demonstrating the Role of Supplemental Vitamin D in the Treatment of COPD

Due to the increasing desire to explore the role of vitamin D2/D3 in treating lung diseases like asthma, 


\section{Cureus}

COPD, and cystic fibrosis, many studies have been conducted so far with inconsistent results either due to a small sample size or some other limitations. A meta-analysis of 25 randomized controlled trials (RCTs) was recently performed to see the efficacy of using this vitamin to treat emphysema and chronic bronchitis with positive results regarding acute exacerbations, lung functions, six-minute walk distance, COPD assessment score, and sputum [28]. Data extracted from our selected studies are presented in tabular form (Table 3).

\begin{tabular}{|c|c|c|c|c|c|c|c|c|c|}
\hline Author & $\begin{array}{l}\text { Year } \\
\text { of } \\
\text { study }\end{array}$ & Study type & $\begin{array}{l}\text { Sample } \\
\text { size (n) }\end{array}$ & Variables studied & $\begin{array}{l}\text { Drug dose (IU) and } \\
\text { MOA }\end{array}$ & $\begin{array}{l}\text { Length of } \\
\text { intervention }\end{array}$ & Maintenance or additional dose & $\begin{array}{l}\text { Baseline mean } \\
\text { serum 25(OH)D }\end{array}$ & $\begin{array}{l}\text { Treatment- } \\
\text { related adverse } \\
\text { events }\end{array}$ \\
\hline $\begin{array}{l}\text { Lehouck et } \\
\text { al. [29] }\end{array}$ & 2012 & RCT & 182 & $\begin{array}{l}\text { Exacerbations of } \\
\text { COPD }\end{array}$ & 100,000 PO, monthly & One year & NA & $20 \mathrm{ng} / \mathrm{mL}$ & $\begin{array}{l}\text { Mild, } \\
\text { asymptomatic } \\
\text { hypercalcemia }\end{array}$ \\
\hline $\begin{array}{l}\text { Hornikx et } \\
\text { al. [30] }\end{array}$ & 2012 & $\begin{array}{l}\text { Subgroup } \\
\text { analysis RCT }\end{array}$ & 50 & $\begin{array}{l}\text { Exercise } \\
\text { performance, } \\
\text { health-related QOL, } \\
\text { lung functions }\end{array}$ & $100,000 \mathrm{PO}$, monthly & $\begin{array}{l}\text { Three } \\
\text { months }\end{array}$ & NA & $20 \mathrm{ng} / \mathrm{mL}$ & Nil \\
\hline $\begin{array}{l}\text { Martineau } \\
\text { et al. [31] }\end{array}$ & 2014 & RCT & 240 & $\begin{array}{l}\text { Exacerbations and } \\
\text { URI }\end{array}$ & $\begin{array}{l}\text { 120,000 PO, every two } \\
\text { months }\end{array}$ & One year & NA & $\begin{array}{l}\text { Group1 }(<50 \mathrm{ng} / \mathrm{mL}) \\
\text { Group } 2(50 \text { and } \\
\text { above) }\end{array}$ & $\begin{array}{l}\text { Decreased } \\
\text { parathyroid } \\
\text { hormone levels }\end{array}$ \\
\hline $\begin{array}{l}\text { Gharabaghi } \\
\text { et al. [32] }\end{array}$ & 2013 & $\begin{array}{l}\text { An } \\
\text { experimental } \\
\text { unblended } \\
\text { open-label trial }\end{array}$ & 25 & $\begin{array}{l}\text { Exercise tolerance } \\
\text { in elderly (6MWD } \\
\text { and FEV1) }\end{array}$ & 50,000 PO, weekly & $\begin{array}{l}\text { Four to } \\
\text { eight weeks }\end{array}$ & NA & $\begin{array}{l}\text { Mean: } 14.05 \mathrm{ng} / \mathrm{mL} \\
\text { Group } 1(<10 \mathrm{ng} / \mathrm{mL}) \\
\text { Group } 2(10-30 \\
\mathrm{ng} / \mathrm{mL})\end{array}$ & $\begin{array}{l}\text { Transient } \\
\text { hypercalciuria } \\
\text { (20\% study } \\
\text { population) }\end{array}$ \\
\hline Khan [33] & 2017 & RCT & 120 & Exacerbations & 2000 , oral daily & Six months & $\mathrm{NA}$ & $24.08 \mathrm{ng} / \mathrm{mL}$ & $\begin{array}{l}\text { Not } \\
\text { documented }\end{array}$ \\
\hline $\begin{array}{l}\text { Zendedel } \\
\text { et al. [34] }\end{array}$ & 2015 & RCT & 88 & $\begin{array}{l}\text { FEV1 and } \\
\text { exacerbations }\end{array}$ & $100,000 \mathrm{PO}$, monthly & Six months & NA & Not determined & $\begin{array}{l}\text { Not } \\
\text { documented }\end{array}$ \\
\hline $\begin{array}{l}\text { Sluyter et } \\
\text { al. [35] }\end{array}$ & 2017 & RCT & 442 & ung functions & $\begin{array}{l}\text { 200,000 PO, loading } \\
\text { dose once }\end{array}$ & $\begin{array}{l}\text { One year } \\
\text { and one } \\
\text { month }\end{array}$ & 100,000 IU monthly & $61 \mathrm{nmol} / \mathrm{L}$ & Nil \\
\hline $\begin{array}{l}\text { Moosavi } \\
\text { Javad et al. } \\
\text { [36] }\end{array}$ & 2015 & $\begin{array}{l}\text { Before and } \\
\text { after clinical } \\
\text { trial }\end{array}$ & 59 & Lung functions & $\begin{array}{l}\text { 300,000-600,000 IM, } \\
\text { loading dose once }\end{array}$ & 12 weeks & 50,000 IU weekly for 12 weeks & $13 \mathrm{ng} / \mathrm{mL}$ & $\begin{array}{l}\text { Not } \\
\text { documented }\end{array}$ \\
\hline $\begin{array}{l}\text { Sanjari et } \\
\text { al. [37] }\end{array}$ & 2016 & RCT & 135 & FEV1 and FVC & $\begin{array}{l}\text { Group I: } 50,000 \\
\text { (vitamin D3) Group II: } \\
0.25 \mu \mathrm{\mu g} \text { (calcitriol) PO, } \\
\text { daily }\end{array}$ & Seven days & NA & $>50 \mathrm{ng} / \mathrm{mL}$ & Nil \\
\hline $\begin{array}{l}\text { Alavi } \\
\text { Foumani et } \\
\text { al. [38] }\end{array}$ & 2019 & RCT & 63 & $\begin{array}{l}\text { Spirometry findings } \\
\text { and quality of life }\end{array}$ & 50,000 PO, weekly & Eight weeks & Once a month for four months & $18.55 \mathrm{ng} / \mathrm{mL}$ & $\begin{array}{l}\text { Not } \\
\text { documented }\end{array}$ \\
\hline $\begin{array}{l}\text { Van de } \\
\text { Bool et al. } \\
\text { [39] }\end{array}$ & 2017 & RCT & 81 & $\begin{array}{l}\text { Exercise } \\
\text { performance and } \\
\text { muscle strength }\end{array}$ & $\begin{array}{l}6.7 \mu \mathrm{g} \mathrm{PO}, \text { BID-TID } \\
125 \mathrm{~mL} \text { per serving }\end{array}$ & $\begin{array}{l}\text { Four } \\
\text { months }\end{array}$ & $\begin{array}{l}\text { Other ingredients of nutritional } \\
\text { supplement }\end{array}$ & $<50 \mathrm{ng} / \mathrm{mL}$ & $\begin{array}{l}\text { Stomach ache, } \\
\text { constipation, } \\
\text { weight loss }\end{array}$ \\
\hline $\begin{array}{l}\text { Bjerk et al. } \\
\text { [40] }\end{array}$ & 2013 & RCT & 36 & $\begin{array}{l}\text { Physical } \\
\text { performance }\end{array}$ & 2000 PO, daily & ix weeks & NA & $23.5 \mathrm{ng} / \mathrm{mL}$ & Nil \\
\hline $\begin{array}{l}\text { Rafiq et al. } \\
\text { [41] }\end{array}$ & 2017 & Pilot trial & 50 & $\begin{array}{l}\text { Respiratory muscle } \\
\text { strength and } \\
\text { physical } \\
\text { performance }\end{array}$ & 1200 PO, daily & Six months & 400 IU daily & $42.3 \mathrm{ng} / \mathrm{mL}$ & $\begin{array}{l}\text { Not } \\
\text { documented }\end{array}$ \\
\hline $\begin{array}{l}\text { Pourrashid } \\
\text { et al. [42] }\end{array}$ & 2018 & RCT & 70 & $\begin{array}{l}\text { Quality of life in } \\
\text { hospitalized patients } \\
\text { with exacerbations }\end{array}$ & $\begin{array}{l}\text { 300,000 IM, single } \\
\text { dose }\end{array}$ & - & NA & $10-11 \mathrm{ng} / \mathrm{mL}$ & $\begin{array}{l}\text { Not } \\
\text { documented }\end{array}$ \\
\hline $\begin{array}{l}\text { Dastan et } \\
\text { al. [43] }\end{array}$ & 2019 & RCT & 70 & $\begin{array}{l}\text { Serum levels of } \\
\text { systemic } \\
\text { inflammatory }\end{array}$ & $\begin{array}{l}\text { 300,000 IM, single } \\
\text { dose }\end{array}$ & - & NA & $11.25 \mathrm{ng} / \mathrm{mL}$ & $\begin{array}{l}\text { Not } \\
\text { documented }\end{array}$ \\
\hline
\end{tabular}




\section{Cureus}

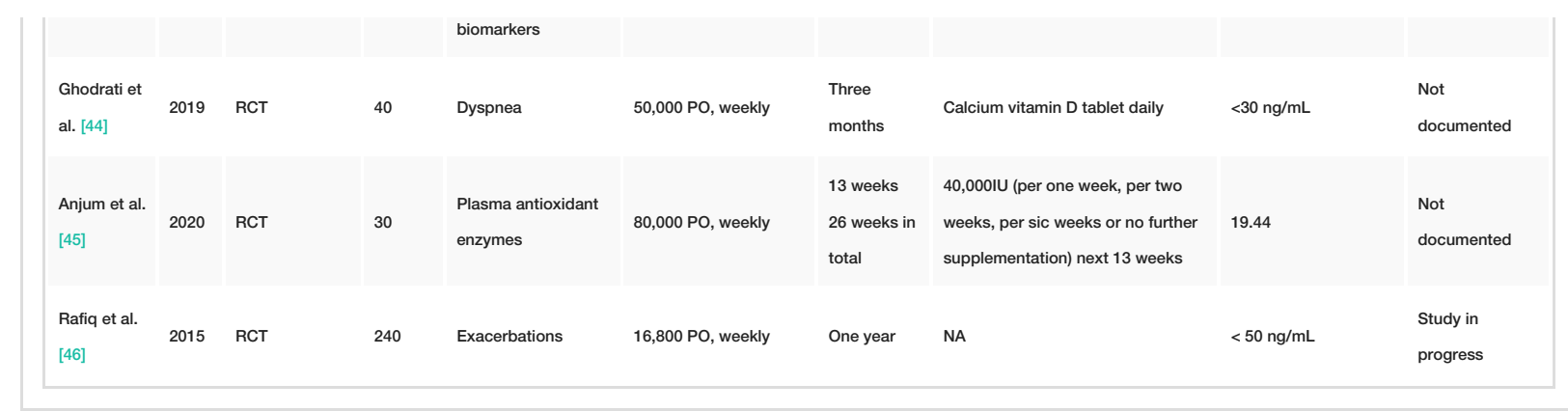

TABLE 3: Data Extracted From RCTs

PO: peroral; IM: intramuscular; BID: twice a day; TID: thrice a day; FEV1: forced expiratory volume; FVC: forced vital capacity; QOL: quality of life; 6MWD: six-minute walk distance; URIs: upper respiratory infections; RCT: randomized controlled trial

Some of the common primary outcomes of those clinical trials are exacerbations, lung functions (FEV1, FEV1/FVC), quality of life, physical exercise, and muscle strength. Lehouck's study could not find any significant effects on the first onset of exacerbation or its frequency, quality of life, hospitalizations, and mortality after giving high dose calcitriol [29]. In comparison, Hornix et al. performed a subgroup analysis on people with very low baseline $25(\mathrm{OH}) \mathrm{D}$ levels from Lehouck's study population, which showed positive results in improving inspiratory muscle strength [30]. Later on, many RCTs proved this vitamin to be protective of the frequency of acute exacerbations of COPD [31,33,34].

Lung functions like FEV1 and FVC showed significant improvement by receiving 100,000IU of vitamin D monthly for six months, but baseline 25(OH)D levels were not recorded in this study [34]. Gharabaghi et al. and Sluyter et al. reported improved FEV1 in subgroups like vitamin D insufficient population $(10-30 \mathrm{ng} / \mathrm{mL})$ and ever smokers, particularly with lung diseases (asthma, COPD) or vitamin D deficiency respectively $[32,35]$. In contrast, many studies showed no significant benefits of giving supplemental vitamin D to improve lung functions [36-38]. Older people with obstructive lung diseases and decreased 25(OH)D levels often need rehabilitation exercise to improve their muscle strength and physical activity. This effect can be enhanced even more if their vitamin D levels are corrected by giving high dose supplements [29,32,39]. However, short term calcitriol supplementation and a pilot trial failed to obtain similar results $[40,41]$.

Both single high dose intramuscular and oral supplemental vitamin D seems to have beneficial effects on health-related quality of life $[42,38]$. We could not find many trials on mortality or disease prognosis as a primary outcome. Still, most of them reported no significant change seen when studied as a secondary outcome of the trials $[29,42,43]$.

As we reviewed earlier observational studies demonstrating the role of hypovitaminosis $\mathrm{D}$ in disease severity, progression, poor outcome, increased inflammation, and symptoms of emphysema or chronic bronchitis, little is known from experimental studies in this field. More clinical trials are required to explore these parameters of disease in detail. Dastan et al. documented the effect of vitamin D supplements on inflammation resolution by measuring serum levels of inflammatory markers [43]. Ghodrati et al. performed a clinical trial and found out the curative role of this vitamin in treating dyspnea in COPD patients [44]. Supplementation can seemingly reduce the progression and morbidity of chronic diseases by decreasing the number of free radicals with antioxidant enzymes, as observed in the latest randomized control trial performed in Bangladesh by Anjum et al. [45]. PRECOVID and Lung VITAL are two large ongoing clinical trials with registration numbers NCT02122627 and NCT01728571, respectively. Their results might add to the evidence regarding vitamin D's effectiveness in controlling disease exacerbations and lung functions $[46,47]$.

Pharmacologic Perspective of Supplemental Vitamin D

In RCTs, mostly the oral route of drug administration was used; only two experimented with high dose intramuscular bolus vitamin D with significant improvement in the quality of life, symptoms of acute exacerbation of COPD, and inflammation resolution $[42,43]$. These studies did not document any side effects related to parenteral or bolus drug regime.

An animal trial performed on mice has put forward a new hypothesis that vitamin $\mathrm{D}$, when used topically/intrapulmonary, can exert a healing effect on lung alveolar cells. This can provide a future subject to explore that inhalational can be an effective mode of administration with less systemic side effects. The healing or curative effect of this vitamin needs further human trials [48]. Transient asymptomatic hypercalcemia or hypercalciuria was reported by two studies that used high dose oral vitamin D supplements $(100,000 I U$ PO monthly and 50,000IU PO weekly) $[29,32]$. We couldn't find much data regarding the safety of 
drug intervention from our studies.

Low dose intervention performed for a shorter duration of time often failed to demonstrate beneficial effects of vitamin D on patients with emphysema or chronic bronchitis $[40,37]$. But these results are inconclusive because sufficient baseline $25(\mathrm{OH}) \mathrm{D}$ levels might have played along with the results [37]. In another study, vitamin D showed no potential effects on the disease parameters used in higher doses for a shorter time [36]. A huge knowledge gap exists that needs further work regarding the pharmacologic properties of calcitriol supplementation.

Effect of baseline 25(OH)D levels on results of the clinical trials: A subgroup analysis performed on 30 severely vitamin D deficient patients (serum 25(OH)D levels $<10 \mathrm{ng} / \mathrm{mL}$ ) raised a concern about the relationship between low baseline $25(\mathrm{OH}) \mathrm{D}$ levels and its beneficial effects on calcitriol supplementation [29]. In contrast, Gharabaghi et al. observed a significant increase in 6MWD and FEV1 in the vitamin D insufficient group (serum $25(\mathrm{OH}) \mathrm{D}=10-30 \mathrm{ng} / \mathrm{mL}$ ) as compared to the vitamin D deficient group (serum $25(\mathrm{OH}) \mathrm{D}<10 \mathrm{ng} / \mathrm{mL})$ [32]. But later on, many studies showed similar results as Lehouck et al. and added to the hypothesis that people with low serum $25(\mathrm{OH}) \mathrm{D}$ levels benefit more from supplemental vitamin $\mathrm{D}$ $[31,42,43]$. Many authors attributed their failure to obtain the desired outcome to either inclusion of vitamin D sufficient samples or the exclusion of vitamin D deficient COPD patients [37,38,41]. Other than vitamin D deficient or insufficient population, ever smokers with hypovitaminosis D or asthma/COPD are the groups who can get more benefits from the use of vitamin D as a therapeutic agent [35]. More studies are required on larger populations involving smokers to explore this effect.

Limitations

There were only a limited number of clinical trials available that satisfied the full selection criteria. The outcomes discussed in the studies were usually widespread and only few were in the desired spectrum of interest. Side effects related to supplemental use of vitamin D were reported by only handful of studies.

\section{Conclusions}

We reviewed the relationship between vitamin D and COPD. The efficacy, safety, and pharmacological properties of calcitriol supplements used in treating obstructive lung diseases remained our focus areas. The reviewed studies show that hypovitaminosis D is more prevalent in COPD patients, and it affects the disease symptoms, severity, progression, exacerbations, prognosis, mortality, lung functions, inflammation, and quality of life. This supplementation can reduce the number of disease exacerbations, inflammation resolution, improving physical exercise, muscle strength, and lung functions (FEV1, FEV1/FVC). In general COPD patients with vitamin D deficiency or insufficiency and smokers, benefit more from calcitriol supplementation.

Oral supplements were used most commonly, but the parenteral route also gave successful results. Some of our studies reflect that using higher doses of vitamin D for a longer duration of time gave relatively more significant results than lower doses. Still, overall results were inconclusive, and very few studies commented on the safety profile of these supplements. In the future, pharmacologic aspects and the safety of calcitriol supplements should be explored in detail. More studies are needed to talk about the alveolar healing and repairing properties of vitamin D as seen in animal models. Inhalational formulations might be the best way to administer it with the least systemic side effects however human trials are required to provide evidence. Conclusively, with the correct amount of evidence vitamin D could act as a novel curative agent for treating COPD in the future.

\section{Additional Information}

\section{Disclosures}

Conflicts of interest: In compliance with the ICMJE uniform disclosure form, all authors declare the following: Payment/services info: All authors have declared that no financial support was received from any organization for the submitted work. Financial relationships: All authors have declared that they have no financial relationships at present or within the previous three years with any organizations that might have an interest in the submitted work. Other relationships: All authors have declared that there are no other relationships or activities that could appear to have influenced the submitted work.

\section{References}

1. World Health Organization. Evidence-Informed Policy Network: EVIPnet in Action . (2019). http://www.who.int/evidence.

2. Global Initiative for Chronic Obstructive Lung Disease (GOLD). Global Strategy for the Diagnosis, Management and Prevention of COPD. (2020). https://goldcopd.org/wp-content/uploads/2019/12/GOLD2020-FINAL-ver1.2-03Dec19_WMV.pdf.

3. Greiller CL, Suri R, Jolliffe DA, et al.: Vitamin D attenuates rhinovirus-induced expression of intercellular adhesion molecule-1 (ICAM-1) and platelet-activating factor receptor (PAFR) in respiratory epithelial cells. J Steroid Biochem Mol Biol. 2019, 187:152-159. 10.1016/j.jsbmb.2018.11.013 
4. Ferrari R, Caram LM, Tanni SE, Godoy I, Rupp de Paiva SA: The relationship between Vitamin D status and exacerbation in COPD patients- a literature review. Respir Med. 2018, 139:34-38.

10.1016/j.rmed.2018.04.012

5. GBD 2015 Chronic Respiratory Disease Collaborators: Global, regional, and national deaths, prevalence, disability-adjusted life years, and years lived with disability for chronic obstructive pulmonary disease and asthma, 1990-2015: a systematic analysis for the Global Burden of Disease Study 2015. Lancet Respir Med. 2017, 5:691-706. 10.1016/S2213-2600(17)30293-X

6. Wedzicha JA, Seemungal TA: COPD exacerbations: defining their cause and prevention . Lancet. 2007, 370:786-796. 10.1016/S0140-6736(07)61382-8

7. Pilz S, Zittermann A, Trummer C, et al.: Vitamin D testing and treatment: a narrative review of current evidence. Endocr Connect. 2019, 8:27-43. 10.1530/EC-18-0432

8. Maretzke F, Bechthold A, Egert S, et al.: Role of vitamin D in preventing and treating selected extraskeletal diseases-an umbrella review. Nutrients. 2020, 12:969. 10.3390/nu12040969

9. Fleet JC: The role of vitamin D in the endocrinology controlling calcium homeostasis . Mol Cell Endocrinol. 2017, 453:36-45. 10.1016/j.mce.2017.04.008

10. Kokturk N, Baha A, Oh YM, Young Ju J, Jones PW: Vitamin D deficiency: what does it mean for chronic obstructive pulmonary disease (COPD)? A comprehensive review for pulmonologists. Clin Respir J. 2018, 12:382-397. 10.1111/crj.12588

11. Islam S, Sarkar NK, Mujahid AA, et al.: Association of serum vitamin D (25OHD) level with acute exacerbation of chronic obstructive pulmonary disease. Mymensingh Med J. 2019, 28:441-448.

12. Oţelea M, Raşcu A, Postolache P: Interrelationship between pathophysiological mechanisms of vitamin D deficit and chronic obstructive pulmonary disease. Rev Med Chir Soc Med Nat Iasi. 2016, 120:497-502.

13. Norman AW, Bouillon R, Whiting SJ, Vieth R, Lips P: 13th workshop consensus for vitamin D nutritional guidelines. J Steroid Biochem Mol Biol. 2007, 103:204-205.

14. Persson LJ, Aanerud M, Hiemstra PS, Hardie JA, Bakke PS, Eagan TM: Chronic obstructive pulmonary disease is associated with low levels of vitamin D. PLoS One. 2012, 7:38934. 10.1371/journal.pone.0038934

15. Anar C, Yüksel Yavuz M, Güldaval F, Varol Y, Kalenci D: Assessment of osteoporosis using the FRAX method and the importance of vitamin D levels in COPD patients. Multidiscip Respir Med. 2018, 13:1. 10.1186/s40248-017-0116-1

16. Białek-Gosk K, Rubinsztajn R, Białek S, Paplińska-Goryca M, Krenke R, Chazan R: Serum vitamin D concentration and markers of bone metabolism in perimenopausal and postmenopausal women with asthma and COPD. Adv Exp Med Biol. 2018, 1070:27-36. 10.1007/5584_2018_157

17. Zhu M, Wang T, Wang C, Ji Y: The association between vitamin D and COPD risk, severity, and exacerbation: an updated systematic review and meta-analysis. Int J Chron Obstruct Pulmon Dis. 2016, 11:2597-2607. 10.2147/COPD.S101382

18. Janssens W, Bouillon R, Claes B, et al.: Vitamin D deficiency is highly prevalent in COPD and correlates with variants in the vitamin D-binding gene. Thorax. 2010, 65:215-220. 10.1136/thx.2009.120659

19. Kim C, Ko Y, Jung JY, et al.: Severe vitamin D deficiency is associated with emphysema progression in male patients with COPD. Respir Med. 2020, 163:105890. 10.1016/j.rmed.2020.105890

20. Hirai K, Shirai T, Suzuki Y, Shimomura T, Itoh K: Comparison of the association between circulating vitamin D3 levels and clinical outcomes in patients with asthma and chronic obstructive pulmonary disease: a prospective observational study. Biol Pharm Bull. 2019, 42:1861-1866. 10.1248/bpb.b19-00385

21. Heath AK, Hodge AM, Ebeling PR, et al.: Circulating 25-hydroxyvitamin D concentration and cause-specific mortality in the Melbourne Collaborative Cohort Study. J Steroid Biochem Mol Biol. 2020, 198:105612. 10.1016/j.jsbmb.2020.105612

22. Mattila T, Vasankari T, Rissanen H, Knekt P, Sares-Jäske L, Jääskeläinen T, Heliövaara M: Airway obstruction, serum vitamin D and mortality in a 33-year follow-up study. Eur J Clin Nutr. 2019, 73:10241032. 10.1038/s41430-018-0299-3

23. Færk G, Çolak Y, Afzal S, Nordestgaard BG: Low concentrations of 25-hydroxyvitamin D and long-term prognosis of COPD: a prospective cohort study. Eur J Epidemiol. 2018, 33:567-577. 10.1007/s10654-0180393-9

24. Botros RM, AbdElsalam Besibes MM, Bahaaeldin AM, Abo Elyazed S: Vitamin D status in hospitalized chronically Ill patients. J Am Coll Nutr. 2018, 37:578-582. 10.1080/07315724.2018.1446194

25. Xu J, Bartz TM, Chittoor G, et al.: Meta-analysis across Cohorts for Heart and Aging Research in Genomic Epidemiology (CHARGE) consortium provides evidence for an association of serum vitamin D with pulmonary function. Br J Nutr. 2018, 120:1159-1170. 10.1017/S0007114518002180

26. Carson EL, Pourshahidi LK, Madigan SM, et al.: Vitamin D status is associated with muscle strength and quality of life in patients with COPD: a seasonal prospective observation study. Int J Chron Obstruct Pulmon Dis. 2018, 13:2613-2622. 10.2147/COPD.S166919

27. Kim C, Jung JY, Kim YS, et al.: Vitamin D deficiency is associated with rapid decline in exercise capacity in male patients with chronic obstructive pulmonary disease. Respiration. 2016, 91:351-358. $10.1159 / 000445266$

28. Li X, He J, Yu M, Sun J: The efficacy of vitamin D therapy for patients with COPD: a meta-analysis of randomized controlled trials. Ann Palliat Med. 2020, 9:286-297. 10.21037/apm.2020.02.26

29. Lehouck A, Mathieu C, Carremans C, et al.: High doses of vitamin D to reduce exacerbations in chronic obstructive pulmonary disease: a randomized trial. Ann Intern Med. 2012, 156:105-114. 10.7326/0003-4819156-2-201201170-00004

30. Hornikx M, Van Remoortel H, Lehouck A, et al.: Vitamin D supplementation during rehabilitation in COPD: a secondary analysis of a randomized trial. Respir Res. 2012, 13:84. 10.1186/1465-9921-13-84

31. Martineau AR, James WY, Hooper RL, et al.: Vitamin D3 supplementation in patients with chronic obstructive pulmonary disease (ViDiCO): a multicentre, double-blind, randomised controlled trial. Lancet Respir Med. 2015, 3:120-130. 10.1016/S2213-2600(14)70255-3

32. Gharabaghi MA, Ghrabaghi MA, Arabi M, Anaraki MRZ, Deilami GD: High dose vitamin D3 improves exercise tolerance in elderly patients with chronic obstructive pulmonary disease. J Gerontol Geriat Res. 
2013, 2:3. 10.4172/2167-7182.1000127

33. Khan DM, Ullah A, Randhawa FA, Iqtadar S, Butt NF, Waheed K: Role of Vitamin D in reducing number of acute exacerbations in Chronic Obstructive Pulmonary Disease (COPD) patients. Pak J Med Sci. 2017, 33:610-614. 10.12669/pjms.333.12397

34. Zendedel A, Gholami M, Anbari K, Ghanadi K, Bachari EC, Azargon A: Effects of vitamin D intake on FEV1 and COPD exacerbation: a randomized clinical trial study. Glob J Health Sci. 2015, 7:243-248. 10.5539/gjhs.v7n4p243

35. Sluyter JD, Camargo CA, Waayer D, Lawes CMM, Toop L, Khaw KT, Scragg R: Effect of monthly, high-dose, long-term vitamin D on lung function: a randomized controlled trial. Nutrients. 2017, 9:1353. 10.3390/nu9121353

36. Moosavi SAJ, Shoushtari MH: The effects of vitamin D supplementation on pulmonary function of chronic obstructive pulmonary disease patients, before and after clinical trial. Diseases. 2015, 3:253-259. 10.3390/diseases3040253

37. Sanjari M, Soltani A, Habibi Khorasani A, Zareinejad M: The effect of vitamin D on COPD exacerbation: a double-blind randomized placebo-controlled parallel clinical trial. J Diabetes Metab Disord. 2016, 15:33. 10.1186/s40200-016-0257-3

38. Alavi Foumani A, Mehrdad M, Jafarinezhad A, Nokani K, Jafari A: Impact of vitamin D on spirometry findings and quality of life in patients with chronic obstructive pulmonary disease: a randomized, double-blinded, placebo-controlled clinical trial. Int J Chron Obstruct Pulmon Dis. 2019, 14:1495-1501. 10.2147/COPD.S207400

39. Van de Bool C, Rutten EPA, van Helvoort A, Franssen FME, Wouters EFM, Schols AMWJ: A randomized clinical trial investigating the efficacy of targeted nutrition as adjunct to exercise training in COPD. J Cachexia Sarcopenia Muscle. 2017, 8:748-758. 10.1002/jcsm.12219

40. Bjerk SM, Edgington BD, Rector TS, Kunisaki KM: Supplemental vitamin D and physical performance in COPD: a pilot randomized trial. Int J Chron Obstruct Pulmon Dis. 2013, 8:97-104. 10.2147/COPD.S40885

41. Rafiq R, Prins HJ, Boersma WG, Daniels JM, den Heijer M, Lips P, de Jongh RT: Effects of daily vitamin D supplementation on respiratory muscle strength and physical performance in vitamin D-deficient COPD patients: a pilot trial. Int J Chron Obstruct Pulmon Dis. 2017, 12:2583-2592. 10.2147/COPD.S132117

42. Pourrashid MH, Dastan F, Salamzadeh J, Eslaminejad A, Edalatifard M: Role of Vitamin D replacement on health-related quality of life in hospitalized patients with "acute exacerbation of chronic obstructive pulmonary disease". Iran J Pharm Res. 2018, 17:801-810.

43. Dastan F, Salamzadeh J, Pourrashid MH, Edalatifard M, Eslaminejad A: Effects of high-dose vitamin D replacement on the serum levels of systemic inflammatory biomarkers in patients with acute exacerbation of chronic obstructive pulmonary disease. COPD. 2019, 16:278-283. 10.1080/15412555.2019.1666812

44. Ghodrati S, Ezzatpanah A, Asadi-Khiavi M, Alian Samakkah S, Esmaeilzadeh A, Pezeshgi A: Administration of vitamin D to ameliorate dyspnea of chronic obstructive pulmonary disease patients: a randomized controlled trial. Immunopathol Persa. 2019, 5:22.

45. Anjum S, Ali T, Bennoor KS, et al.: Vitamin D3 supplementation on plasma antioxidant enzymes in D3 deficient patients with COPD - a randomized controlled trial. J Bangladesh Soc Physiologist. 2020, 15:23-32. 10.3329/jbsp.v15i1.48112

46. Rafiq R, Aleva FE, Schrumpf JA, et al.: Prevention of exacerbations in patients with COPD and vitamin D deficiency through vitamin D supplementation (PRECOVID): a study protocol. BMC Pulm Med. 2015, 15:106. 10.1186/s12890-015-0101-4

47. Gold DR, Litonjua AA, Carey VI, et al.: Lung VITAL: rationale, design, and baseline characteristics of an ancillary study evaluating the effects of vitamin D and/or marine omega-3 fatty acid supplements on acute exacerbations of chronic respiratory disease, asthma control, pneumonia and lung function in adults. Contemp Clin Trials. 2016, 47:185-195. 10.1016/j.cct.2016.01.003

48. Horiguchi M, Hirokawa M, Abe K, Kumagai H, Yamashita C: Pulmonary administration of 1,25dihydroxyvitamin D3 to the lungs induces alveolar regeneration in a mouse model of chronic obstructive pulmonary disease. J Control Release. 2016, 233:191-197. 10.1016/j.jconrel.2016.05.006 